\title{
Disciplinamiento vs. reinvención del espacio americano: teorías de lo costero/insular en José Lezama Lima*
}

\author{
Kevin Sedeño Guillén ${ }^{1}$ \\ University of Kentucky (EE.UU)
}

\section{Resumen}

El artículo explora una historia de la mitología insular en la ensayística del escritor cubano José Lezama Lima. Para documentar esa historia el texto se remonta al trabajo del también ensayista y profesor cubano José Juan Arrom. Se analiza la enunciación de una teoría de lo costero/insular en la entrevista sostenida entre Lezama Lima y Juan Ramón Jiménez, recogida en Coloquio con Juan Ramón Jiménez (1938). De igual modo se estudian los planteamientos de Friedrich Hegel sobre una supuesta relación entre geografía e historia y la recepción de Lezama Lima de esos planteamientos.

Palabras clave: José Lezama Lima, Juan Ramón Jiménez, Friedrich Hegel, insularidad.

\section{Abstract}

This paper explores a history of the island mythology in Cuban writer José Lezama Lima's essays. To document this history the text uses the work of also Cuban essayist and Professor José Juan Arrom. The enunciation of a coastal/island theory in the interview between Lezama Lima and Juan Ramón Jiménez, collected in Coloquio con Juan Ramón Jiménez (1938) is analyzed. At the same time Friedrich Hegel's views on an alleged relationship between geography and history, and the reception of Lezama Lima of those approaches are studied.

Keywords: José Lezama Lima, Juan Ramón Jiménez, Friedrich Hegel, insularity.

\footnotetext{
* Discipline vs. Reinvention of America's Space: Seaside/Island Theories in José Lezama Lima.

${ }^{1}$ Candidato doctoral del programa de Estudios Hispánicos de la Universidad de Kentucky (EE.UU). Master en Artes, con mención en Estudios Hispánicos de la misma Universidad. Profesional en Estudios Literarios de la Universidad Nacional de Colombia (Bogotá). e-mail: kevin.sedeno-guillen@uky.edu
} 
A José Lezama Lima (1910-1976)

y José Juan Arrom (1910-2007),

en sus más de cien años con nosotros.

En la cartomancia o adivinación por medio de los naipes el nueve de oros indica el mar o un viaje por él. Existen además mancias de adivinación por el agua de ríos y manantiales, pero no por la del mar (Collin de Planci, 1977: 83). El Diccionario de la Lengua Española, de la Real Academia de la Lengua, define por su parte el término "isla" como una porción de tierra rodeada de agua por todas partes. La definición misma me hace respirar un destino trágico, una sensación indescriptible de ahogamiento y prisión. Pero la primera impresión personal al respecto la tuve en la caribeña ciudad de Santiago de Cuba que, según escuché decir allá, vive y crece "de nalgas al mar". Me pareció lícito entonces, tomando la parte por el todo -como lo hacían los documentos coloniales, que se referían a la antigua capital como Cuba a secas- decir lo mismo de Cuba toda. Intuí entonces que el cubano es, extrañamente, un pueblo que ha vivido gran parte de su historia de nalgas o, al menos, de espaldas al mar.

El verdadero destello me vendría sin embargo, de manera enigmática, al leer un verso del poema "Madre cubana", del recién fallecido poeta soviético Evgueni Evtushenko (1933-2017) que visitó Cuba en la década del '60 del siglo XX: "El mar (...) por donde vinieron los asesinos" (1997: 114), escribía refiriéndose a la invasión por playa Girón o Bahía de Cochinos. El verso, por lo demás poco evocador poéticamente, alude a una asociación más general que pareciera caracterizar la relación de los cubanos con el mar como una de distanciamiento, de asociación con el peligro o fuente de males externos. Lo que me resultaba más enigmático estaba en el origen del destello: no era un poeta cubano quien me alertaba, sino uno soviético. Quizás Evtushenko fuera inocente de las implicaciones históricas de su afirmación o tal vez no, pero de las palabras de este visitante de la antigua metrópoli socialista me resultó una ansiedad obsesiva. Mi inquietud me llevó al extenso catálogo de materias de la Biblioteca Nacional "José Martí", en La Habana, y en el constaté, hace ya algunos años, que desde el epígrafe correspondiente a INSUFICIENCIA RENAL se pasaba a INSULINA, pero de "insularidad", nada. Mi desconocimiento parecía no ser sólo mío, como me lo revelaba esta búsqueda de 1997 . No recuerdo cómo llegué a los versos alumbradores de José Lezama Lima, Virgilio Piñera y Dulce María Loynaz, y tras ellos a los de sus antecesores, que trecho a trecho fueron construyendo, sin embargo, unos de los mitos más persistentes y difusos de la cultura cubana, ignorado por el catálogo mencionado. Estos hechos, o percepciones, al parecer aislados, me fueron conduciendo, a través de un largo periodo, a una comprensión 
más estructurada del problema de la insularidad cubana, que paso a exponer en las siguientes secciones.

\section{“[S]iempre tierra"}

A José Juan Arrom (1910-2007) le correspondió establecer una trayectoria de Cuba como objeto de la imaginación que sirve de marco a mi preocupación: "[...] siglo tras siglo, para representarla o describirla, los poetas de Cuba han acudido a imágenes que esencialmente son variaciones o metaforizaciones de una misma idea nuclear. Esa idea nuclear es tierra: tierra contemplada de cerca o añorada de lejos, pero siempre tierra" (1985: 135). Y la poca tierra de una isla lo es precisamente por su relación con el mar, lo que apunta hacia una compleja estructura de símbolos que atan a la tierra, isla, mar, agua, soledad, exilio y una miríada de imágenes que conforman el conglomerado simbólico de lo insular. La "tierra" como núcleo central de estas metaforizaciones cubanas me parece limitada para abarcar la trayectoria acrecentada de la imagen de la nación en su literatura.

La isla es por su parte una representación que abarca el carácter de los pares tierra y mar. Tendríamos así una triada de elementos que en su interferencia mutua sustentan la noción que se dilucida y que me llevará a esa parcela de lo cubano que José Lezama Lima (19101976) bautizó como "insularidad". En el estudio citado, Arrom se remonta al pasado literario de Cuba en la búsqueda de las imágenes de la nación que para él tienen su centro en la tierra: "Y a medida que esa imagen prolifera en variantes o se desdobla en metáforas, unas y otras se polarizan hacia dos posturas igualmente constantes: una es eufórica, arcádica, paradisíaca, de gozosa contemplación de su belleza; la otra es patética, angustiosa, pesimista, de pesarosa meditación de los males que la asedian" (1985: 135). Acierta Arrom al enunciar lo prolífico de esa imagen que se reproduce en múltiples metáforas, más aún al formular una estructuración de esta proliferación simbólica en dos posturas: la arcádica y la patética: "Ambas posturas, además, se resumen en dos frases que nos llegan desde nuestros lejanos orígenes literarios: 'isla la más hermosa que ojos hayan visto' y 'triste tierra, como tierra tiranizada y de señoría'”.

El fundador de la postura arcádica sería Cristóbal Colón, que en su Diario de navegación se refiere a Cuba como "isla la más hermosa [...]", viendo, más allá de la Isla real, las maravillas orientales concebidas por el imaginario europeo. Para respirar con él en el territorio de este primer acercamiento, habría que historiar la amplia presencia de las islas míticas en el imaginario de los antiguos y de la Europa 
medieval. La postura patética se remite al maestro Miguel Velázquez que enunciara la citada frase -"triste tierra [...]"- en carta al obispo Sarmiento. ${ }^{2}$ La relación con la imagen de Cuba es distinta en este sacerdote consagrado a la enseñanza en la primera mitad del siglo XVI que en el conquistador Colón. En Velázquez, la isla bella es suya, pero esclava y la tiranía a la que está sometida la hace triste. Si Colón se conforma con admirar y exagerar un poco la belleza de la isla, que espera que pueda contribuir a acrecentar el patrimonio de los reyes de España y el suyo propio, poco más de cincuenta años después el maestro Velázquez se posiciona, por encima de lo natural, participando en la inauguración de una cultura propia que parte de una profunda raíz ética.

Quizás las dos posturas enunciadas por Arrom no sean tan esencialmente antitéticas, aunque algunos autores privilegien una u otra zona de la imagen poética de Cuba. De lo que ellas parecen hablar no es de una Cuba en sí, sino de posiciones subjetivamente relacionales que dependen de la posición con respecto a la Isla en que han sido colocados por el devenir, sea la del viajero, la del rebelde, la del conquistador o la del exiliado, por mencionar sólo algunas de estas posibles relaciones. Tierra poseída o perdida, pero siempre tierra.

\section{Coloquio con Juan Ramón Jiménez: ¿resaca vs. "sentimiento de lontananza? ${ }^{3}$}

"Ya va siendo hora de que todos nos empeñemos en una Economía Astronómica, en una Meteorología habanera para uso de descarriados y poetas, en una Teleología Insular, en algo de veras grande y nutridor."

José Lezama Lima.

\footnotetext{
${ }^{2}$ Velázquez pertenecía a esa primera generación nacida en la Isla, descendiente de una mujer indígena y de un pariente del conquistador Diego Velázquez, lo que le dio la posibilidad de estudiar en Sevilla y en Alcalá de Henares, y de ejercer como canónigo de la catedral de Santiago de Cuba (Guerra 76). Henríquez Ureña presenta a Miguel Velázquez como el primer maestro cubano y como un rebelde (1967: I, 23-24). Lamentablemente, de su carta sólo se conserva un fragmento reproducido en la Colección de documentos inéditos relativos al descubrimiento, conquista y organización de las antiguas posesiones de Ultramar (1866: 292).

${ }^{3}$ Debo agradecer muy especialmente a Lesbia Orta Varona, bibliógrafa y referencista de Cuban Heritage Collection, Otto G. Richter Library, University of Miami y Humberto López Cruz, profesor del Department of Modern Languages and Literatures, de University of Central Florida, por haberme facilitado copias de distintas ediciones del "Coloquio" y bibliografía adicional de gran valor y difícil consecución.
} 
Puestos a explorar lo que va de estos ancestros literarios al manifiesto que constituye la enunciación de la "Teleología insular" por José Lezama Lima en su Coloquio con Juan Ramón Jiménez (1938), hay un profuso mar simbólico que no ha sido suficientemente visionado como conjunto poético en su relación de totalidad con la construcción de una mitología insular, que constituía el propósito lezamiano: la construcción del mito que nos faltaba, una teleología, con el propósito de superar la descripción de la naturaleza, propia del concepto de lo histórico en Aristóteles, por una poética de la historia, un procurarse datos que está en la raíz de lo histórico, pero reubicado en función de la superación del fracaso del devenir de lo cubano (Vitier, 2001 s. p.). El Coloquio es un texto fundacional en que se despliega la búsqueda lezamiana en torno a "lo cubano" y que se funda en un mito que aunque ha estado siempre ahí, en condición de latencia, ha pasado desapercibido a sus antecesores y sólo en Lezama alcanza su formulación y llega a definirse: "La ínsula distinta en el Cosmos o lo que es lo mismo, la ínsula indistinta en el Cosmos'”, como testimonia Vitier que rezaba uno de los aforismos del primer número de Espuela de Plata (1939) (Vitier, 1970: 73). A esta teleología ve Lezama abocado lo cubano, "[...] obligados forzosamente por fronteras de agua” (Lezama cit. en Vitier, 1994: 319).

Aunque el lenguaje del Coloquio con Juan Ramón Jiménez no desmerece el hermetismo propio de otras zonas de la obra lezamiana, quizás podría afirmarse que las propuestas centrales del mismo están orientadas a responder a fuertes presiones externas que se dan sobre la Isla en el período en que tuvo lugar esta conversación entre Juan Ramón Jiménez y José Lezama Lima. "Una mano fuerte aprieta, estrangula un limón, define una garganta" (Lezama, 1938: 74 ), dice el poeta cubano a propósito de procesos de definición e identidad que se condicionan a partir del ejercicio de una violencia externa al cuerpo que pugna por definirse, cuerpo y piel en sus mutuos encuentros y desencuentros.

La primera pregunta que le dirige Lezama Lima a Jiménez -en aquella biblioteca habanera de los años 30 en que tuvo lugar la entrevistaplantea de una vez el que será el tema central del diálogo: “¿no ha percibido ciertos elementos de sensibilidad (cosa que nada tiene que ver con la etapa actual de nuestra lírica ni con lo más visible de nuestra sensibilidad), que nos hagan pensar en la posibilidad del 'insularismo'?" (1938: 76). La pregunta indica que lo que se busca está en el terreno de la "sensibilidad", que no aspira a ninguna forma de verificación. Se erige además en un terreno opuesto al de los movimientos poéticos contemporáneos en la Isla, tema sobre el que volveremos más adelante, y al referirse a su término clave: 
"insularismo", lo hace entre comillas, lo que nos hace pensar que ya se encontraba circulando y que tal vez Lezama no lo aceptara en toda la amplitud de su significado. Formulada la pregunta no deja de acotar que va dirigida a un poeta y que no le interesa una respuesta sociológica o estadística al respecto. Semejante en su carácter directo es la respuesta de Juan Ramón Jiménez:

\begin{abstract}
Si la pregunta no es una "salida" ¿qué estensión le da usted al concepto "insularismo"? Porque si Cuba es una isla, Inglaterra es una isla, Australia es una isla y el planeta en que habitamos es una isla. Y los que viven en islas deben vivir hacia dentro. Además, si se habla de una sensibilidad insular, habría que definirla o, mejor, que adivinarla por contraste. En este caso, ¿frente a qué, oponiéndose a qué otra sensibilidad, se levanta este tema de la sensibilidad diferente de las islas? [sic] (76).
\end{abstract}

El poeta andaluz parece dudar por un momento de la seriedad de la interrogante de su interlocutor, pero de inmediato ingresa a una especie de dialogismo socrático. La forma más fácil de salir del atoro a que lo conduce la cuestión, es acudir al argumento de la inexistencia de las islas, el cual carece de validez si partimos de que, aunque todas las tierras del planeta estén rodeadas de agua de uno u otro modo, la noción de "isla" tiene profunda presencia en la geografía y el imaginario global, no sólo de Occidente. A pesar de esas dudas iniciales, Juan Ramón Jiménez deja establecido en esta primera intervención un precepto que ocupará parte importante de la conversación, respecto a que los habitantes de isla deben vivir hacia dentro, hacia dentro de la isla se entiende. Además, propone una profundización en la noción de "sensibilidad insular" y el modo de percibirla. La rápida respuesta de Lezama Lima precisa que: "'Insularismo' ha de entenderse no tanto en su acepción geográfica, que desde luego no deja de interesarnos, sino, sobre todo, en cuanto problema que plantea la historia de la cultura y aún de la sensibilidad" (76). Podríamos decir quizás que Lezama Lima se aproxima a una "geopoética", volviendo sobre el tema europeo del determinismo geográfico sobre la cultura y encomendándose a la "ciencia cultural" de Max Scheler (1874-1928). Aunque en una segunda acepción del término, que sólo ejemplifica sin definirla, se refiere a la idea de Francia como una isla.

En una próxima intervención, Juan Ramón Jiménez recurre a sus conocimientos en materia de sensibilidad insular, apelando a la

\footnotetext{
${ }^{4}$ Scheler conformaría, junto a Leo Frobenius y Oswald Spengler, el espiritualismo romántico que propugnaba la separación Cultura-Hombre.
} 
"desesperación por aislamiento" propia de los irlandeses, como lo presenta Joyce en Ulysses (1922). Mientras que Lezama Lima acude a la autoridad del antropólogo Leo Frobenius (1873-1938), quien propuso la distinción entre culturas del litoral y de tierra adentro: "Las islas plantean cuestiones referentes a las culturas de litoral. Interesa subrayar esto desde el punto de vista sensitivo, pues en una cultura de litoral interesará más el sentimiento de lontananza que el de paisaje propio" (Lezama, 1938: 77). Ese "sentimiento de lontananza" será el primer asidero que propone Lezama en su intención de repensar la cultura de las islas y estará referido a la relación del ser insular con lo distante, con las culturas externas, con el Otro. ${ }^{5}$ De seguido, reafirma la idea de Juan Ramón Jiménez de que el ser insular ha de vivir hacia adentro, lo que nos hace pensar que el sentimiento de lontananza sería un efecto disociador de la cultura insular.

Juan Ramón Jiménez responde a su vez refiriéndose a dos de los poetas más queridos por Lezama: "Lo que provocó la calidad poética en Martí o en Casal, dos de los más expresivos estilos sensibles de Cuba, fue una reacción contra las culturas incorporadas. No se ve en la diferencia que los caracteriza nada que nos haga pensar en un estímulo insular legítimo. Lo mejor de ellos está en el diverso universalismo a que tiende su obra" (77). Antes de responder a este dardo, Lezama acude a unos versos de Alfonso Reyes para intentar "adivinar por contraste" -como había propuesto Jiménezla "sensibilidad insular cubana", contrastada con "la sensibilidad mexicana continental" (78).

Si México sirve de contraste, Inglaterra actúa como isla arquetípica en relación con Cuba. De este modo - plantea Lezama Lima- si Inglaterra se siente ajena a Europa: "nosotros los cubanos nunca hemos hecho mucho caso de la tesis del hispanoamericanismo, y ello señala que no nos sentimos muy obligados con la problemática de una sensibilidad continental. La estabilidad y reserva de una sensibilidad continental contrastan con la búsqueda superficial ofrecida por nuestra sensibilidad insular" (79). ${ }^{6}$ Además de presentarse la problemática de la inclusión de Cuba en proyectos identitarios regionales, ya sea el del Caribe o de Latinoamérica, ${ }^{7}$ nos estaríamos viendo con una

\footnotetext{
${ }^{5}$ Para Cintio Vitier, el sentimiento de lontananza sería el anverso del mito de la insularidad, mientras que el aporte de la resaca sería su reverso (2001a).

${ }^{6}$ Sin embargo, años después Lezama se daría a la tarea de explorar esa "sensibilidad continental" en La expresión americana (1957). Véase al respecto, Mataix (200). Disponible también en la Biblioteca Virtual Cervantes.

${ }^{7}$ Sobre la relación de Cuba con proyectos de integración caribeña o latinoamericana, véase Rojas (2000: 35-40).
} 
forma de la negatividad insularidad, que sentimos conectada con aquella "etapa actual de nuestra lírica" a la que Lezama había aludido inicialmente y sobre la que ahora se explaya:

\begin{abstract}
[...] la brusquedad con que la poesía cubana planteó de una manera quizás desmedida, la incorporación de la sensibilidad negra. Olvidando otros incitantes, la resaca, y desvinculándola ahora de su más estricta alusión, es quizás el primer elemento de sensibilidad insular que ofrecemos los cubanos dentro del símbolo de nuestra sensibilidad de lontananza. La resaca no es otra cosa que el aporte que las islas pueden dar a las corrientes marinas, mientras que los trabajos de incorporación se lastran de un bizantinismo cuyo límite está en producir en el litoral un falso espejismo de escamas podridas, en crucigramas viciosos (79-80).
\end{abstract}

En la cita anterior aflora el malestar de Lezama Lima en torno a la poesía negrista, vinculada al "sentimiento de lontananza" por haber sido este un movimiento que se inició en París y que sólo a manera de eco se desarrollaría en el Caribe. Antes ya lo ha tildado de superficial, ahora completa sus apóstrofes denominándolo "falso espejismo de escamas podridas", en relación con el exotismo que generó y la auto-otrificación propiciada. Pero más allá de la contrucción de su proyecto insular a partir del Otro, identificado en el movimiento de la poesía negrista, Lezama introduce otra noción clave dentro de su propuesta: la resaca. Con esto queda claro que para él es más importante lo que las islas dan que lo que reciben del exterior. Resacar es volver a sacar, es aquel movimiento de las olas, retrocediendo después de haber llegado a la costa; implica por tanto que antes de alejarse otra vez, las olas dejan en las orillas lo que traen, pero cuando regresan lo hacen llevando consigo un producto distinto al que dejaron a su llegada. En esto radica el universalismo de la propuesta lezamiana, ajena a cualquier chovinismo nacionalista y consciente de la necesidad, a pesar del aislamiento geográfico insular, de alimentar y ser alimentados por las corrientes marinas que nos conectarían con otras islas y también con otros continentes.

Juan Ramón Jiménez insiste en la necesidad de internación de la cultura cubana y en que hemos "estado más atentos a los barcos que les llegaban que al trabajo de su resaca" (80). Al reproche se sobrepone la constatación de que la propuesta de Lezama apunta a la creación de un mito y lo prematuro entonces de pedir la verificación de "una sensibilidad ya definida". Lezama Lima coincide con la anterior insinuación juanramoniana, confesando categóricamente que "desearía nada más que la introducción al estudio de las islas 
sirviese para integrar el mito que nos falta". Tras darle incesantes rodeos acercatorios a su verdadero propósito, Lezama ha confesado aquí el deseo mayor que subyace en la intención de hacer de la cultura insular un terreno propiciatorio de estudios: "el mito que nos falta", a la que atribuía él las tribulaciones de nuestra nación en lo cultural.

Mas Juan Ramón no se deja convencer fácilmente: "El mito de la sensibilidad insular, de que usted habla, pudiera ser también suscitador de un orgullo disociativo, que quizás los apartase a ustedes prematuramente de una solución universalista" (81). En esto insiste más adelante cuando iguala el proyecto insular lezamiano con la "expresión mestiza" como reverso, es decir, con el movimiento de la poesía negrista: "Las dos tesis parece que promueven un orgullo diferente, una solución disociadora por desemejanza y esclusión. La tesis de la sensibilidad insular va contra la sensibilidad continental y la de la espresión mestiza contra la espresión de valores y angustias universales" (85-86). En su condición de escritor europeo, aunque periférico doblemente por español y andaluz, no comprende el conflicto del artista caribeño y latinoamericano al intentar dialogar con la cultura occidental en igualdad de condiciones, desde un mismo plano epistemológico. Cualquier toma de posición válida del artista caribeño implicaría, en un primer momento, un rompimiento con las reglas de la cultura en Occidente, como premisa para el inicio de la descolonización de sus saberes.

La respuesta de Lezama Lima no puede dejar de apuntar a que: "La expresión de los andaluces no tiene que ver nada con el andalucismo; las exigencias de una sensibilidad insular no tienen tangencias posibles con una solución de mestizaje artístico. Aquella asciende de la historia al espíritu, ésta no es más que un recuento bizantino del detalle, un disfrute epicúreo y elemental de factores exógenos" (89). Al equiparar a la poesía negrista con el andalucismo, en lo que ambos proyectos pueden tener de folcloristas, Lezama intenta un complejo camino de traducciones culturales que se identifica con las propuestas de Jiménez en contra de la superficialidad de estas manifestaciones culturales en su propio contexto, a la vez que le ilustra un camino de comprensión de lo cubano, ajeno para Jiménez, que pasa por lo propio andaluz. Salvada esta resistencia Lezama Lima esta preparado para delinear la centralidad de su proyecto:

Nosotros, obligados forzosamente por fronteras de agua a una teleología, a situarnos en la pista de nuestro único telos, no exageramos al decir que la Argentina, México y Cuba son los tres países hispanoamericanos que podrían organizar una expresión. Nosotros, insulares, hemos vivido sin religiosidad, 
bajo especies de pasajeros accidentes, y no es nuestra arrogancia lo que menos nos puede conducir al ridículo. Hemos carecido de orgullo de expresión, nos hemos recurvado al vicio, que es elegancia en la geometría desligada de la flor, y la obra de arte no se da entre nosotros como una exigencia subterrígena sino como una frustración de la vitalidad (91).

Lezama ve abocada a Cuba a una teleología, precisamente a una teleología insular, lo que resulta en la instalación de la geografía insular y su correspondiente geopoética en el centro de la cultura de la isla. Esto significa que sus fronteras de agua superarían su función geográfica para ocupar un espacio determinante en el terreno de los significados culturales y en la revaloración de las relaciones con la cultura insular y con las culturas extrainsulares. Dentro de esta teleología insular las nociones de "sentimiento de lontananza" -relación del ser insular con las culturas externas- y de "resaca" -"aporte que las islas pueden dar a las corrientes marinas"-, establecen una dinámica de revaloración total de la cultura cubana, hacia el pasado, en forma de arqueología y resignificación cultural, y hacia el porvenir, en una refundación por futuridad. Creemos, y correspondería corroborar, que la teleología insular tuvo continuidad en otra construcción teórico-mítica de Lezama Lima: las eras imaginarias.

En el Coloquio con Juan Ramón Jiménez, Lezama se ha propuesto atender a una zona de la sensibilidad cubana, que pretende deslindarse de la historia literaria de la Cuba que le es contemporánea y de todo signo de visibilidad cultural. La recomendación del vivir hacia dentro, dirigida a los habitantes de isla, es la primera condición planteada por Juan Ramón Jiménez en este Coloquio trascendente. Mientras que Lezama fundamenta su geopoética de lo insular en un "sentimiento de lontananza", entendido como relación del ser insular con el Otro, quizás elemento de efecto disociador, y en la resaca, como símbolo de lo que las islas dan a las aguas marinas que las rodean. En esto radicaría el universalismo de la propuesta, a pesar del explícito deseo de dar cuenta del deslinde cubano de proyectos identitarios regionales. Los anteriores símbolos y metáforas terminan por articularse como mito en la propuesta lezamiana, adquiriendo la dimensión de teleología insular, proyecto revalorizador de lo cubano que anidaría pletóricamente en el grupo Orígenes.

Este propósito lezamiano no puede separarse de la realización de Orígenes (1944-1956), revista, grupo y generación literarios que se convertiría en punto de encuentro de lo mejor de la cultura hispanoamericana y euronorteamericana de la época. En Orígenes 
confluyen un grupo de poetas cubanos que alcanzarían luego máxima relevancia, junto a dos andaluces que se incorporaron al proyecto: Juan Ramón Jiménez con su antología La poesía en Cuba en 1936 (1937) y María Zambrano con su ensayo "La Cuba secreta" (1948). ${ }^{8}$ La publicación por Lezama, años después, de la Antología de la poesía cubana (1965), en tres densos tomos, es el resumen y puesta en escena del mito largamente incubado. ${ }^{9}$ Se ocupa en ella de la reconfiguración del canon poético insular, teniendo como propósito implícito la construcción del mito que nos faltaba, para incidir desde la poesía en el devenir histórico de Cuba. Para Lezama: "Nuestra isla comienza su historia dentro de la poesía [...] Así el almirante Cristóbal Colón consigna en su Diario, libro que debe estar en el umbral de nuestra poesía, que vio caer, al acercarse a nuestras costas, un gran ramo de fuego en el mar" (Lezama, 1965: 215).

Historia y poesía quedan entrelazadas desde el inicio de nuestros tiempos históricos, remitiendo el nacimiento de la literatura nacional al Diario de Colón. Sea una estrella anunciando la promesa del "Nuevo Mundo" o un trágico anuncio de la temporada ciclónica que cada octubre llega a las islas del Caribe, ese "gran ramo de fuego sobre el mar" es para Lezama una primera seducción de nuestra luz. La frase lo impacta como incitación poética fundante y la coloca en el "Prólogo" a las puertas mismas de su concepción de lo cubano: "En el reflejo inverso si yo digo; bosque de la Germania o ramo de fuego en el mar, o simplemente cortejo, estoy formando una pertenencia distinta, pero que se dilata y recorre" (1942: 11. Las cursivas son del autor) -vuelve sobre la afortunada frase colombina en otro de sus ensayos- marcado por ella la siente dilatarse y recorrer el tiempo futuro de la poesía cubana. El "Prólogo" no sólo se propone servir de introducción a la poesía que antologa, sino que se delata Lezama "[...] en el trance de encontrarle una tradición" a los cosas cubanas y palpa con alegría en esta labor que: "La imagen se va imponiendo a lo caótico y a la fabulación oscura" (219). Lo europeo venido en andas de fabulaciones medievales y de mitologías clásicas, vendría a ser suplantado por nuestra propia imagen, la que emerge de una tradición naciente. Va encontrándole tradición a nuestra repostería, pastelería, a la música, que ya en el siglo XVI, cuenta con un artista

\footnotetext{
${ }^{8}$ Véase Jiménez (1937) y Zambrano (1948). Sobre la relación de estos autores con Cuba, véanse mis artículos: "Viaje iniciático de María Zambrano a la isla secreta: pensamiento insular y vivencia caribeña del exilio en Cuba y Puerto Rico." (Cámara y Ortega, 2011: 91-104) у " 'Como a tierra propia, como a patria suya, patria americana, patria insular': reflexiones insulares de tres andaluces en Cuba: Federico García Lorca, Juan Ramón Jiménez y María Zambrano." (Buffery; Lough; Marcer \& Sánchez, 2012: 57-66).

${ }^{9}$ Véase Antología de la poesía cubana, de Lezama Lima (1965.)
} 
de Málaga y otro de Sevilla, entre otros: "Lo desconocido es casi nuestra única tradición" (Lezama, 1960: 35), se lamenta en el "A partir de la poesía", sustentando su afán mitificador. Hállale también raíz al internamiento, proceso por el que las poblaciones costeras, huyendo de los piratas, buscan el interior de la Isla, las sabanas y al mismo tiempo le dan la espalda al mar; inaugurando esa constante nuestra de enajenación del entorno marino, de dar la espalda, de encerramiento y miedo a lo exterior, que tan profunda marca ha tenido en la evolución social y cultural posterior de la nación cubana.

La propuesta de una teleología insular puede ser entendida a la luz de la urgencia manifestada por Lezama de provocar la eclosión de nuevos mitos: "Todo tendrá que ser reconstruido, invencionado de nuevo, y los viejos mitos, al reaparecer de nuevo, nos ofrecerán sus conjuros y sus enigmas con un rostro desconocido. La ficción de los mitos son nuevos mitos, con nuevos cansancios y terrores" (Lezama, 1957: 373-374). La imagen sería erigida como el criterio último para establecer la "verdadera realidad de un hecho o su indiferencia o inexistencia". La teleología insular, ese primer énfasis lezamiano en la particularidad cubana, se comprende dentro de este esfuerzo posterior, concéntrico y abarcador, para comprender nuevamente la identidad americana:

He aquí el germen del complejo terrible del americano: creer que su expresión no es forma alcanzada, sino problematismo, cosa a resolver. Sudoroso e inhibido por tan presuntuosos complejos, busca en la autoctonía el lujo que se le negaba, y acorralado entre esa pequeñez y el espejismo de las realizaciones europeas, revisa sus datos, pero ha olvidado lo esencial, que le plasma de su autoctonía, es tierra igual que la de Europa. Y que las agujas para el rayo de nuestros palacios, se hacen de síntesis, como la de los artesanos occidentales, y que hincan, como el fervor de aquellos hombres, las espaldas de un celeste animal, igualmente desconocido y extraño. Lo único que crea cultura es el paisaje y eso lo tenemos de maestra monstruosidad, sin que nos recorra el cansancio de los crepúsculos críticos. Paisaje de espacio abierto, donde no se alzará, como en los bosques de la Auvernia, la casa del ahorcado (376).

Pronunciándose sobre la ansiedad mítica de Lezama, Vitier valora de forma enfática su irrupción en el panorama literario cubano cuando expresa: "Nuestra poesía, como si nada hubiera ocurrido, tomaba contacto, soñadoramente, con el anhelo mítico inmemorial que estaba en la imagen renacentista de la isla y, poniéndose al amparo de 
la virgen que es fecundada por el rayo de luz y de los pacientes oros de los transcursos naturales, comenzaba de nuevo matinalmente su discurso" (Vitier, 1970: 69).

\section{Contra el disciplinamiento hegeliano del espacio americano}

“[...] lo que importa comprender es por qué un pueblo que se desplaza se detiene de pronto y se adscribe a un paisaje. Es como un hombre que avanza entre las mujeres y de pronto queda prendido, prendado de una".

José Ortega y Gasset, "En el centenario de Hegel".

El libro de Georg Wilhelm Friedrich Hegel (1770-1831) Vorlesungen über die Philosophie der Geschichte $(1837,1840)$ fue traducido al español para la Revista de Occidente por José Gaos como Lecciones sobre la filosofía de la historia universal (1928). En el número de la revista de febrero de ese mismo año -anticipándose a la publicación de la traducción del libro de Hegel- José Ortega y Gasset (18831955), director de la revista, publicó un texto que debía fungir como prólogo de la edición española del libro de Hegel, titulado "La Filosofía de la historia de Hegel y la historiología", que sería incluido luego en las obras completas de Ortega y Gasset. Con posterioridad, Ortega y Gasset publica el texto "En el centenario de Hegel" (1931) en el que, entre otros elementos, analiza el capítulo 2 de las Lecciones sobre la filosofía de la historia universal titulado "La conexión de la naturaleza o los fundamentos geográficos de la historia universal", en el que Hegel propone las conexiones del espacio geográfico con su planteamiento de una filosofía de la historia.

La filosofía de la geografía hegeliana parte de que el “...tipo de localidad, [...] corresponde exactamente al tipo y carácter del pueblo, hijo de tal suelo" (Hegel, 1997:162), estableciendo deterministamente una "base geográfica" para el desarrollo del espíritu. Analizando el texto, refiere Ortega y Gasset que: "La nación es espíritu mineralizado y animalizado; por tanto, adscrito a un lugar, a un paisaje. La historia con su enjambre de pueblos brota de la geografía" (1931: 111). Añade que: "Para mí, existe una relación simbólica entre nación y territorio. Los pueblos emigran en busca de su paisaje afín, que en el secreto fondo de su alma les ha sido prometido por Dios. La tierra prometida es el paisaje prometido" (114). La interpretación de Ortega y Gasset no se corresponde 
exactamente con la de Hegel, lo que Ortega y Gasset mismo reconoce, quizás la supere, al entender la relación entra nación y territorio como una simbiosis simbólica. Paso seguido, sobre la base de la correspondencia entre geografía e historia, Hegel reordena la jerarquía de los pueblos de la Tierra:

[...]ni la zona cálida ni la fría permiten al hombre elevarse a la libertad de movimientos, ni le conceden aquella abundancia de medios, que le permite pensar en los intereses más elevados, espirituales. El hombre se mantiene en estas zonas harto embotado; la naturaleza lo deprime; no puede por tanto separarse de ella, que es lo que constituye la primera condición de una cultura espiritual elevada. La violencia de los elementos es demasiado grande, para que el hombre pueda vencerlos en la lucha y adquirir poderío bastante para afirmar su libertad espiritual frente al poder de la naturaleza. El hielo que hace encogerse a los lapones o el calor ardiente de África, son poderes demasiado grandes, para que, bajo su peso, adquiera el hombre la libertad de movimiento y aquella riqueza que es necesaria para dar forma consciente a una realidad culta. En aquellas zonas la necesidad es incesante y no puede evitarse nunca; el hombre se ve constantemente forzado a dirigir su atención a la naturaleza. El hombre necesita de la naturaleza para sus fines; pero cuando la naturaleza es demasiado poderosa, no se ofrece al hombre como medio. Por eso las zonas cálida y fría no son el teatro de la historia. Estas regiones extremas quedan excluidas del espíritu libre, desde este punto de vista (1997: 163-164).

La concepción de Hegel, largamente incubada en el pensamiento europeo, considera la naturaleza como una enemiga que es necesario vencer para poder construir la cultura, con el consiguiente efecto nefasto sobre la ecología del planeta que resulta de la instauración de una modernidad imbuida de este espíritu. De igual modo, Hegel ha restringido la zona del planeta susceptible de ser el "teatro de la historia" a la zona templada, especialmente a la "parte septentrional" de esta, mientras que América, Asia y África son descalificadas en su posibilidad de adquirir una "cultura espiritual elevada", pues carecerían según él de "libertad espiritual”, lo que las haría incapaces de construir una "realidad culta". ${ }^{10}$ Desde una perspectiva geográfica, Hegel está convirtiendo a tres de los continentes del planeta en víctimas de la naturaleza, en individuos incapacitados para construir

${ }^{10}$ Ortega y Gasset había analizado previamente ese texto en relación con la idea hegeliana de América. Véase: "Hegel y América". El Espectador. t. VII, 1930. No lo he podido consultar durante la redacción de este ensayo. 
la historia, salvajes "embotados", seres "deprimidos", y de esta manera, justificando el orden geopolítico de su supeditación a una minoría asentada en el norte del planeta.

Esta disquisición geográfica constituye la razón teóricometodológica de que Hegel sólo incluya en sus Lecciones sobre filosofía de la historia universal, el mundo oriental, incluyendo en él a China, India, Persia, Fenicia, Siria, Israel y Egipto; el mundo griego; el mundo romano y el mundo germánico -según él conformado básicamente por Alemania- excluyendo todo el continente americano, África, buena parte de Asia, e incluso el sur de Europa. Los planteamientos de Hegel son, nuclearmente, una de las bases ideológicas del proyecto de expansión imperial europeo que colonizó Asia y África durante el siglo XIX. Es claro, entonces, como lo propone González-Stephan que: "El determinismo subyacente en la filosofía de Hegel reveló una adecuada justificación -políticamente inconsciente- del proceso histórico que se estaba llevando a cabo en Occidente, autorizando su movilidad conquistadora frente a los espacios restantes, tenidos por zonas pasivas y estériles a la espera de ser colonizadas" (2002: 112). Definidas estas premisas, que son sus perspectivas "filosóficas" de la geografía, Hegel presenta la que considera la determinación más general que las diferencias naturales le imponen a la historia:

[...] es la relación entre el mar y la tierra. Con respecto a la tierra se presentan tres diferencias fundamentales. Nos encontramos, en primer lugar, con altiplanicies sin agua; en segundo lugar, con valles surcados por ríos; y en tercer lugar, con litorales. Estos tres elementos son los más esenciales que se ofrecen al concepto que verifica la distinción. A ellos podemos reducir todas las demás determinaciones" (165).

La teoría hegeliana del espacio quedaría delineada estructuralmente por la relación entre la tierra y el mar. La primera modalidad delimitada de esa relación serían las llanuras sin agua, residencia de pueblos nómadas, de carácter pacífico primordialmente, que no conocen la agricultura. La segunda ubicaría valles fértiles formados por grandes corrientes de aguas, lugares ideales para la constitución de centros de cultura, en los que se practica la agricultura, que da origen a la previsión, la propiedad, el derecho y el arte. Al trasladar esta tipología a la Europa moderna señala que:

En las épocas modernas, habiéndose afirmado que los Estados deben estar separados por elementos naturales, nos hemos acostumbrado a considerar al agua como elemento 
que separa. Frente a esto hay que afirmar que no hay nada que una tanto como el agua. Los países civilizados no son más que comarcas regadas por una corriente de agua. El agua es lo que une. Las montañas separan. Los países separados por montañas lo están mucho más que los separados por un río o incluso por un mar. Así los Pirineos separan a Francia y España. Cádiz está más ligado a América que a Madrid (167).

Desde esta teoría, Andalucía quedaría excluida de Europa y expulsada al espacio americano, inadecuado para ser "teatro de la historia", exclusión que podríamos vincular a los estrechos vínculos que en el imaginario y en la historia habrían establecido estas dos regiones. Los países del tercer elemento -que son los que me interesan particularmente en este texto- son presentados como sigue:

Este tercer elemento es el litoral, la tierra en contacto con el mar y en quienes esta relación se ha desarrollado claramente [...] El mar engendra, en general, una manera propia de vivir. Este elemento indeterminado nos da la representación de lo ilimitado e infinito; y al sentirse el hombre en esta infinitud, anímase a trascender de lo limitado. El mar es lo limitado; no tolera circunscribirse tranquilamente a las ciudades, como el interior. La tierra, el valle, fija el hombre al terruño y lo sitúa en una multitud de dependencias. Pero el mar lo saca de este círculo limitado (168).

Con esta modalidad geográfica Hegel se refiere a aquellos pueblos que viven a la orilla del mar, sin precisar si estos corresponden a territorios continentales o insulares, la definición ofrecida correspondería a ambas variantes. ${ }^{11} \mathrm{Si}$ en una primera aproximación su visión se presenta como positiva, en relación con la percepción de lo ilimitado que el mar propiciaría, considera seguidamente a la navegación como una actividad que propicia la rapiña y la astucia, debido a que:

La planicie infinita es absolutamente blanda; no resiste a la menor presión, ni aun a la de la brisa; parece infinitamente inocente, sumisa, amistosa, adaptada a todo; y precisamente esa facultad de acomodarse a todo es lo que convierte el mar en el elemento más peligroso terrible. Frente a ese engaño, frente a ese poder, el hombre, aes triplex circa pectus, se lanza sobre un liviano leño, confiando solamente en su valor y en su

\footnotetext{
11 "Litoral", según el Diccionario de la lengua española (RAE), es una palabra proveniente del latín "litorālis", que significa "costa del mar", "país" o "territorio".
} 
presencia de ánimo; y abandona la tierra firme para bogar por el inquieto elemento, llevando consigo el suelo, fabricado por él mismo (169).

La valoración de Hegel no sólo termina siendo negativa hacia el hombre de litoral, sino hacia el mar mismo, elemento que es percibido como traicionero, un espacio aventurado que no tiene comparación con la "tierra firme". ¿Habría entonces una tierra que no es firme?, ¿el fondo marino?, ¿la superficie de las islas? Hasta aquí las disquisiciones generales al respecto. Como hemos visto, las islas como tal no aparecen de forma explícita en la concepción de la geografía en la relación con la historia presentada por Hegel, aunque el litoral puede incluirlas. De igual modo, detrás de esa visión de los pueblos de litoral como ávidos de conquista, creo ver la imagen de la Inglaterra imperial. Ortega y Gasset enfatiza su lectura en este aspecto:

Según Hegel, hay tres tipos de tierra para los efectos históricos -lo que llamaría tres paisajes: la altiplanicie, el valle fecundo, la costa. Esta división le ha sido inspirada por la consideración de que nuestro planeta no es sólo tierra, sino también agua. Los tres paisajes se caracterizan por la relación de la tierra al líquido elemento. La altiplanicie es la aridez. El valle es obra del río. En la costa "tremola la marina", como dice Dante (1931: 114-115).

Luego, en la descripción del "Nuevo Mundo", afirma Hegel que: “...el mar de las islas, que se extiende entre América del Sur y Asia, revela cierta inmaturidad por lo que toca también a su origen. La mayor parte de las islas se asientan sobre corales y están hechas de modo que más bien parecen cubrimiento de rocas surgidas recientemente de las profundidades marinas y ostentan el carácter de algo nacido hace poco tiempo" (1997: 170). Terminando el capítulo afirma: "Un Estado europeo no puede ser un verdadero Estado si no tiene nexo con el mar [...] Por eso el principio de la libertad individual ha llegado a ser el principio de la vida de los estados europeos" (199), con lo que parece restablecer un sentido positivo, identificado con el sentido de libertad, a la relación de Europa con el mar.

Lezama discutirá también los prejuicios hegelianos hacia América: "Esa imaginación elemental propicia a la creación de unicornios y ciudades levantadas en una lejanía sin comprobación humana, nos ganaban el calificativo de niños, con que nos regalaba Hegel en sus orgullosas lecciones sobre la Filosofía de la Historia Universal, calificativo que se nos extendía muy al margen de aquella ganancia 
evangélica para los pequeñuelos, sin la cual no se penetraba en el reino" (1957: 381). La referencia realizada por Lezama corresponde al mismo capítulo 2 de las Lecciones sobre la filosofía que hemos discutido antes, por lo que llama la atención que interesado como estaba en la formulación de una teoría de la insularidad, Lezama omita referirse a la propuesta de los tres elementos que Hegel incluía allí. En "Sumas críticas del americano", último ensayo de La expresión americana, Lezama no sólo retoma las reticencias americanistas de Hegel; el "[...] cerrado pesimismo del protestantismo hegeliano" (1957a: 436); sus dislates culinarios que no le merecen ya "comento o glosa" y que deja burlonamente a la consideración de "...los numerosos hegelianos londinenses de la escuela de Whitehead [...]" (437); sino que pareciera lamentar y sorprenderse por la atención prestada por Ortega y Gasset a esos mismos elementos que el ha despreciado: "Lo que todavía nos asombra, es el desatado interés de Ortega y Gasset, por esas siete u ocho páginas donde Hegel enjuicia la América, en su Filosofía de la Historia Universal" (Lezama, 1957a: 437). Estos nuevos elementos responderían la pregunta que hemos formulado más arriba, respecto al por qué Lezama pasa por alto en su configuración de una teleología insular, la geopolítica hegeliana de la altiplanicie, el valle y el litoral.

Al analizar las punzantes críticas de Lezama a Hegel, Chiampi afirma que: "Al optar por la forma en devenir Lezama realiza un nítido calco de los términos de la lógica hegeliana (el devenir como lugar donde se reconcilian el ser y el no ser), sin admitir, empero, las consecuencias que de ella extrae Hegel para su concepto de historia universal" (Chiampi, 1994: 14-15). Disiente también Lezama al optar por la concepción de Schelling, que le permite concebir el paisaje como una forma de revelación del espíritu en la naturaleza, en contraposición a la postura hegeliana (15). Sobre esta base Chiampi llega a la conclusión de que el esquema conceptual de La expresión americana está "[...] decididamente articulado para contestar el hegelianismo" (27), produciendo una ruptura con la lógica y el historicismo hegeliano. Pero ante esta constatación se ve obligada a cuestionarse el por qué de una reacción tan airada que pudiera parecer tardía. Entre las posibilidades que baraja se encuentran una posible reacción a la visión negativa del catolicismo presentada por Hegel, una lectura de Lezama que asociara las ideas del alemán con el germanismo y sus funestos resultados durante y después de la Segunda Guerra Mundial, pero básicamente:

[...] el rechazo lezamiano del historicismo de Hegel es el correlato de su reivindicación -via América- del núcleo genealógico de Occidente. La vieja Europa, la que nace de la incorporación de los grandes mitos 
y religiones de Oriente por el cristianismo primitivo, aquella que preservó la tradición grecorromana (y con ésta el mundo pagano), es la cultura paradigmal, la matriz de los imaginarios de la cultura americana (30).

Chiampi presenta el proyecto lezamiano como una revisión de la modernidad estética, que reclama tanto para ese núcleo cultural antiguo, como para el barroco que lo retoma, la condición de "una modernidad legitima" (32). Esta reluctura de la modernidad desde América coloca a Lezama en una posición adelantada en relación con los estudios comparativos de las culturas americanas y europeas, y lo ubica en un proyecto de revisión y crítica de una concepción eurocéntrica de la cultura. La crítica de Lezama a las propuestas geohistóricas/geopolíticas de Hegel revelan la filiación del filósofo alemán con los autores de la historia natural del siglo XVIII, en su representación negativa de América y los americanos, a lo que Antonello Gerbi denominó como la disputa del Nuevo Mundo. Mientras que Lezama revela su afiliación a un núcleo que tiene sus más lejanos antecedentes en los críticos ilustrados e historiadores de la literatura americana del siglo XVIII que, al contestar a esas representaciones discriminatorias, fundaron por fuera de ellas las bases epistemológicas del pensamiento americano.

\section{Reinvención del espacio insular}

José Lezama Lima no es sólo un lector atento y contradictor de la geohistoria hegeliana, sino también un conocedor de lecturas inaugurales en nuestra lengua de Lecciones sobre la filosofía, como la realizada por José Ortega y Gasset. Pero no sólo tendría acceso Lezama a estas fuentes filosóficas europeas a través de sus lecturas de los textos mencionados u otros. La profunda participación de la andaluza María Zambrano (1904-1991) en el proyecto origenista y en la enunciación de un mito de la insularidad, deviene un vínculo humano que al ponerla en conexión con Lezama lo conecta a su vez con Ortega y Gasset, el maestro de ella, y a través de él con el legado de Hegel. Recuérdese que Zambrano había sido discípula de Ortega y Gasset en la Universidad Central de Madrid, asidua de la tertulia de la Revista de Occidente y mediadora entre Ortega y Gasset y los escritores españoles más jóvenes (Moreno Sanz, 1993: s.p.).

He intentado mostrar la confrontación entre teorías divergentes de lo costero/insular, en el seno de proyectos modernos en disputa. De una parte la teoría geohistórica de los elementos de la naturaleza, en la que se privilegia la relación entre la tierra y el mar, enunciada 
por Hegel, en franca complicidad con un proyecto moderno colonial, diseñado como herramienta para participar del secuestro de toda posibilidad epistemológica para los pueblos no europeos. El litoral es para Hegel una punta de lanza del proyecto expansionista colonial europeo y su teoría sobre el espacio prefigura la conquista de ese territorio que su filosofía mapea. Por otro lado, la teleología insular, enunciada y acariciada largamente por el caribeño José Lezama Lima, como parte de su "sistema poético del mundo", se enuncia como un desafío tendiente a establecer el estatus epistemológico de América, a partir de la negación del proyecto de la modernidad anglo-sajona representado por Hegel y en un retorno a las culturas primigenias y a la primera modernidad postergada. La teleología insular lezamiana se propone quizás una descolonización del imaginario, que como los proyectos de otras naciones postcoloniales, pasa muchas veces por la confrontación en el propio terreno de la cultura imperial. El mito de la insularidad no puede entonces ser leído por fuera de las disputas entre los distintos grupos de poder de la Cuba republicana por imponer un proyecto de nación, dirección que me veo llevado a explorar en próximas lecturas de la herencia lezamiana.

\section{Bibliografía}

Arrom, J. J. (1985). “Cuba: trayectoria de su imagen poética”. En su: En el fiel de América: estudios de literatura hispanoamericana. (135-214). La Habana: Editorial Letras Cubanas.

Cañete Quesada, C. (2006, Fall). "José Lezama Lima y su noción de 'teleología insular': Lectura del Coloquio con Juan Ramón Jiménez". AfroHispanic Review Vol. 25(2): 33-54.

Collin de Planci, S. (1977). Diccionario de profecías y profetas. Buenos Aires: Editorial Tiempo.

Chiampi, I. (1994). “La historia tejida por la imagen”. En: Lezama Lima, José. La expresión Americana. (pp. 9-34). México: Fondo de Cultura Económica.

Evtushenko, E. (1977). "Madre cubana". En: Diego, Eliseo. 30 poetas soviéticos. La Habana: Editorial Arte y Literatura.

Guerra y Sánchez, R. (1989). Manual de historia de Cuba. (3 reimpres.) La Habana: Editorial Pueblo y Educación.

González Stephan, B. (2002). Fundaciones: canon, historia y cultura nacional: la historiografía literaria del liberalismo hispanoamericano del siglo XIX. (2 ed. corregida y aum.) Madrid: Iberoamericana; Frankfurt am Main: Vervuert.

Hegel, Georg W. F. (1997). Lecciones sobre la filosofía de la historia universal. Pról. José Ortega y Gasset. Tr. José Gaos. Madrid: Alianza Editorial. 
Henriquez Ureña, M. Panorama histórico de la literatura cubana. La Habana: Edición Revolucionaria, 1967. 2 t.

Lezama Lima, J. (1938, en.-feb.-mar). “Coloquio con Juan Ramón Jiménez". Revista Cubana. (11): 73-95.

. (1942). “Cumplimiento de Mallarme (1842-1942)” (pp. [10]-12). Confluencias. Selec. y pról. Abel E. Prieto. La Habana: Editorial Letras Cubanas, 1988. Publicado originalmente en (pp. 241-243. Analecta del reloj). La Habana: [Ediciones] Orígenes, 1953.

- (1957). La expresión americana. La Habana: Ministerio de Educación, Instituto Nacional de Cultura. Reproducido en El reino de la imagen. Selec., pról. y cronología Julio Ortega. Caracas: Biblioteca Ayacucho, 1981. 369-441.

(1957). "Mitos y cansancio clásico" (pp. 369-383). La expresión americana.

(1957a). "Sumas críticas del americanismo" (pp. 428-441). La expresión americana.

. (1960). "A partir de la poesía". (pp. 31-53). La cantidad hechizada. . (1965). "Prólogo a una antología" (pp. 213-257). La cantidad hechizada.

(1970). La cantidad hechizada. La Habana: Ediciones Unión.

Moreno Sanz, J. (1993). "Cronología de María Zambrano". La razón en la sombra. Antología del pensamiento de María Zambrano. Madrid: Editorial Siruela.

Ortega y Gasset, J. (1931). "En el centenario de Hegel” (pp. 95-121). Kant, Hegel, Dilthey. José Ortega y Gasset. Hunab Ku, Proyecto Baktun. 12 jun. 2009.

Vitier, C. (1970). "La poesía de José Lezama Lima y el intento de una teleología insular". Recopilación de textos sobre José Lezama Lima. (pp. 68-89). Selección y notas Pedro Simón. La Habana: Casa de las Américas.

(1983). "De las cartas que me escribió Lezama". Casa de las Américas (137): 106-113. Cit. en Cañete, 2006: 52-53, n. 27. (1994). "La aventura de Orígenes". Fascinación de la memoria: textos inéditos de José Lezama Lima. (pp. 309-377). Selec. y pról. de Iván González Cruz. La Habana: Editorial Letras Cubanas. (2001). "Cintio Vitier o la historia como esperanza". Entrevista con Enrique Ubieta. Contracorriente 1.4 (2001), sep. 3 jun. 2002. (2001a, sep.). "La isla infinita”. La Jiribilla: Revista de Cultura Cubana. (18). Consultado el 13 de junio de 2007 desde: http:// www.lajiribilla.co.cu/2001/n18_septiembre/549_18.html 
